\title{
Effects of Liquid Probiotics (Lactobacillus sp.) on Microflora Balance, Enzyme Activity, Number and Surface Area of the Intestinal Villi of Broiler
}

\author{
Muhammad Izzuddiyn ${ }^{1}$, Woro Busono², Osfar Sjofjan² \\ 1. Master Program in Animal Science, Faculty of Animal Husbandry, Brawijaya University, Malang \\ 2. Faculty of Animal Husbandry, Brawijaya University, Malang
}

\begin{abstract}
The aims of this study were to determine the effects of probiotic liquid as a feed additive on productivity, microflora balance, enzym activity, number and surface of intestinal villi of the broiler. A laboratory study with a Complete Randomized Design (CRD) on 144 Day Old Chicks (DOC) Lohman strain was conducted. The treatment was the basal feed without the addition of liquid probiotic (P0); basal feed with 0,2 v/w liquid probiotic (P1); basal feed with 0,4 v/w liquid probiotic $(\mathrm{P} 2)$ and basal feed with $0,6 \mathrm{v} / \mathrm{w}$ liquid probiotic (P3). A liquid probiotic containing the composition of Lactobacillus sp. $1,4 \times 10^{10} \mathrm{cfu} / \mathrm{mLl}$. Data were analyzed using a CRD followed by the Duncan Multiple Range Test. The results showed that liquid probiotic (Lactobacillus sp.) as food additive give the significant effect $(P<0,05)$ to the number of intestinal villi, showed no significant effect $(P>0,05)$ to protease and lipase activity. It's showed a significant effect $(P<0,01)$ to total plate count (TPC) of lactid acid bacteria, Salmonella sp., Eschericia coli, the surface of intestinal villi. The result was concluded that the higher concentration of liquid probiotics in feed the higher microflora balance, protease and lipase activity, number and surface of intestinal villi. Decreasement of Salmonella sp. and Eschericia coli TPC. A liquid probiotic (Lactobacillus sp.) $0.6 \mathrm{v} / \mathrm{w}$ in feed was suggested to produce the higher performance.
\end{abstract}

Keywords: Broilers, Intestinal characteristics, Liquid probiotic

\section{INTRODUCTION}

Use of antibiotics in broilers besides to expected positive impacts but can get negative impacts, among others, stimulate the emergence of bacterial resistance to these antibiotics and cause residue in the meat. The emergence of bacterial resistance can have an effect on reducing the highly beneficial microflora in the intestine, whereas the presence of antibiotic residues can have an allergic or hypersensitivity impact which is one of the precursors of cancer. On this basis, many countries reject animal foods derived from livestock fed antibiotics [1].

The mechanism of probiotics is different from antibiotics, antibiotics kill both pathogen and nonpathogenic microbes, if bacteria cannot be killed because it is resistant then it should be used antibiotics with a broader spectrum. Probiotics play a role to improve the balance of intestinal microflora and increase the number of beneficial microbes so that pathogenic bacteria inhibited. Probiotics also play a role in inhibiting the colonization of pathogenic bacteria by forming a block of digestive coating and removal of pathogen bacteria attached to the intestinal

Correspondence address:

Muhammad Izzuddiyn

Email : izzuddiyn@gmail.com

Address : Master Program in Animal Science, Faculty of

Animal Husbandry, Brawijaya University, Malang epithelium, so that the intestinal villi surface can absorb nutrients efficiently [2].

Lactobacillus sp. is one of the bacteria that can be used as probiotics. Lactobacillus sp. is a major type of microflora in the intestine, including beneficial lactic acid bacteria and has the ability to produce various antagonistic substances to suppress the growth of pathogenic bacteria in order to improve the balance of intestinal microflora [1].

Lactobacillus sp. in the feed used in this study is liquid. The advantage of this liquid probiotic is to have TPC (Total Plate Count) 1.5 times larger than the form of flour. Lactobacillus $\mathrm{sp}$. in liquid form has a TPC of $1.2 \times 10^{10} \mathrm{CFU} / \mathrm{mL}$, while the flour form is $7.2 \times 10^{9} \mathrm{CFU} / \mathrm{mL}$ [4]. The addition of probiotics Lactobacillus sp. In feed with a concentration of $0.6 \%$ can improve the appearance of broiler production [3].

This research will conduct a study on the effect of the addition of liquid probiotic (Lactobacillus sp.) in broiler feed with treatment level based on the research [3]. The results are expected to give the best results on the balance of microflora, enzyme activity, the number and surface area of the intestinal villi. 


\section{RESEARCH METHODS}

Research Material

Chicken used was Lohmann strain as 144 tails are not distinguished between male and female and maintained for 35 days. Liquid probiotic Lactobacillus sp. with bacterial colonies $1,4 \times 10^{10}$ $\mathrm{CFU} / \mathrm{mL}$ [5].

The research method used was field experiment with complete randomized design (RAL) with 4 treatments and each treatment was repeated 6 times, so there were 24 experimental units and each experimental unit consisted of 6 DOC. Total chicken used as many as 144 tails. The treatment given was to use basalt feed with different levels of probiotics. Feed and drinking are given in ad libitum, the method of giving probiotics in the feed was by homogeneously mixing into the feed with the following composition:

$\mathrm{P0}=$ basal feed + liquid probiotic $0 \%(\mathrm{v} / \mathrm{w})$

$\mathrm{P} 1$ = basal feed + liquid probiotic $0.2 \%(\mathrm{v} / \mathrm{w})$

$\mathrm{P} 2=$ basal feed + liquid probiotic $0.4 \%(\mathrm{v} / \mathrm{w})$

P3 = basal feed + liquid probiotic $0.6 \%(\mathrm{v} / \mathrm{w})$

Lactobacillus sp. probiotics include aeorophilic, more tolerant of oxygen than other probiotic bacteria. Mixing at a safe temperature is below $35^{\circ} \mathrm{C}$, for that mixing in the shade, not with sun exposure.

Analysis of food substance content of feed ingredients was done at the Laboratory of Nutrition and Feed, Animal Husbandry Faculty of Brawijaya University. Microflora analysis was conducted in the Microbiology Laboratory of Medical Faculty of Brawijaya University (FKUB). Intestinal histology analysis was performed at the Physiology Anatomy Laboratory of Medical Faculty, Brawijaya University.

\section{Calculation of Intestinal Microflora Balance}

A sample of digesta intestine was taken by sucking the contents of the small intestine (ileum) using a syringe as much as $1 \mathrm{~g}$ and placed on a sterile cup. Further microbiological analysis with calculation of TPC (Total Plate Count) which includes the number of Lactic Acid Bacteria colonies, Escherichia coli, and Salmonella sp. Calculation of BAL colonies using MRS (Mann Ragosa Sharpe) media, calculation of Escherichia coli colony using VRBA (Violet Red Bile Agar) media and Salmonella sp. using SS (Salmonella Shigella) media. The balance of non-pathogenic bacterial colonies and pathogens was at a percentage ratio of $80: 20$ [6].

\section{Calculation of Number and Surface Area of the Villi}

Preparation of Intestinal Samples (Ileum)

The ileum sample was taken from a $3 \mathrm{~cm}$ long piece from Meckel's diverticulum area $4 \mathrm{~cm}$ to the distal direction. Digesta was removed with a syringe, then put in a bottle containing BNF (Neutral Formalin Buffer) solution 10\% [7].

\section{Histology Preparations}

Preparation of histology through stages of fixation, dehydration, molding, slicing, staining Hemotoxylin and Eosin.

\section{Calculation of Villi}

The calculation of Villi was determined based on a number of villi in 10 fields of view from 1 $\mathrm{mm}$ length of ileum using Olympus $\mathrm{CHC}$ microscope with a magnification of $40 x$ and $100 x$ and Optilab viewer [8].

\section{Calculation of Surface Area of the Villi}

The calculation of the surface area of the villi follows Sakamoto, Hirose, Onizuka, Hayashi, Futamura, Kawamura, and Ezaki [9] methods, mathematically formulated as follows:

Surface area of the villi $=(2 \pi A) \times((B \times C)) / 2$ Information :

$$
\begin{aligned}
& A=\text { height of villi }(\mu \mathrm{m}) \\
& B=\text { width of apical villi }(\mu \mathrm{m}) \\
& C=\text { basal width of villi }(\mu \mathrm{m})
\end{aligned}
$$

Activity of Protease and Lipase Enzymes

Formula for the determination of protease and lipase enzyme activity by UV-VIS spectrophotometer method [10].

Protease/Lipase activity $=$ Absorbance $x \mathrm{~F}$

F value for protease activity $\quad: 3361$

F value for lipase activity $\quad: 3971$

Table 1. Basal Feed Structure [11]

\begin{tabular}{lrr}
\hline \multirow{2}{*}{ Feed ingredients } & \multicolumn{2}{c}{ Composition (\%) } \\
\cline { 2 - 3 } & Starter & Finisher \\
\hline Corn & 53,80 & 52,09 \\
Soy meal & 20,60 & 17,86 \\
Bran & 0,00 & 5,00 \\
MBM & 5,00 & 5,00 \\
Coconut meal & 5,00 & 5,00 \\
Local fish meal & 10,00 & 10,00 \\
Coconut oil & 3,97 & 3,65 \\
Salt & 0,24 & 0,13 \\
Dl- Methionine & 0,19 & 0,07 \\
Filler & 1,20 & 1,20 \\
\hline Total & 100,00 & 100,00 \\
\hline
\end{tabular}


Feed

The composition of the broiler's basal feed and prices are listed in Table 1 [11], while the feed proximate results were given in Table 2.

\section{Data Analysis}

The data obtained was calculated using Microsoft Excel program, then analyzed by multiplication analysis (ANOVA) with Complete Random Design. If there is a discrepancy proceed with Duncan's multiple-range test [12]

\begin{tabular}{|c|c|c|c|}
\hline No. & $\begin{array}{l}\text { Food } \\
\text { substance }\end{array}$ & Starter & Finisher \\
\hline 1. & PK (\%) & 23,50 & 22,41 \\
\hline 2. & LK (\%) & 6,82 & 8,09 \\
\hline 3. & SK (\%) & 3,85 & 3,22 \\
\hline 4. & GE (kkal) & 4205,4 & 4500,9 \\
\hline
\end{tabular}

\section{RESULTS AND DISCUSSION}

\section{Microflora Balance}

The effect of probiotics associated with bacterial populations in regulating the balance of intestinal microflora can be determined by counting the total number of viable counts (TVC) and total lactobacillus count (TLC) of the cecum samples given probiotics. Table 3 showed the average calculated number of colonies of BAL, Salmonella, and Escherichia coli.

\section{Number of Lactic Acid Bacteria Colonies (BAL)}

The mean values in Table 3 showed that the highest number of BAL colonies is $\mathrm{P} 3$ while the lowest is P0. The more concentration of probiotics given the higher the number of BAL colonies. These results were consistent with the results of previous research $[13,14,15]$. This result was higher than the results of the study [14] which suggested that the addition of Lactobacillus plantarum probiotics could increase the number of BAL colonies to 8.6 CFU.

The addition of these probiotics could provide an unfavorable acidic atmosphere for the growth of pathogenic bacteria. The possible mechanism was probiotics break down simple carbohydrates into lactic acid, acetic acid, carbon dioxide, $\mathrm{H}_{2} \mathrm{O}_{2}$, bacteriocin, reuterin, and others [1]. Bacteriocin is composed of 17-37 amino acids produced from lactic acid bacteria, comprising the substance of the secreted protein from probiotic bacterial cells that have antibacterial properties [16].

The addition of probiotics will form colonization of probiotics in the digestive tract, resulting in nutritional competition and the location of adhesion (attachment) between probiotics and other bacteria, especially pathogens. The growth of probiotics will also produce a variety of anti-bacterial components (organic acids, hydrogen peroxide, and bacteriocin capable of suppressing the growth of pathogens) [17].

Increased acid conditions cause the environmental $\mathrm{pH}$ to be low and cause pathogenic bacteria do not grow. If Lactobacillus colonizes on the surface of the gastrointestinal tract then this will inhibit colonization of unfavorable bacteria, the activity referred to as competitive exclusion (CE). Lactobacillus that has grown and attached to intestinal epithelial cells forms a colony. In the growth of the colony requires nutrients needed also by pathogenic bacteria, so it happens nutrient competition, this is not beneficial for the growth of pathogenic bacteria [1].

\section{Number of Salmonella Colonies}

The mean values in Table 3 show that the lowest number of Salmonella colonies is found in P3, whereas the highest is PO. The increasing concentration of probiotics given the lower the number of Salmonella colonies. This result is in accordance with the study $[18,19,20]$.

The decrease in the number of Salmonella colonies was consistent with previous research that Lactobacillus probiotics $0.75 \%$ in feed could reduce the number of Salmonella enteritidis [21]. A decrease in the number of Salmonella colonies can be caused by probiotics that can lower the $\mathrm{pH}$ of ileum, so that low $\mathrm{pH}$ conditions can suppress pathogenic bacteria. The decreasing number of Salmonella colonies shows that there is the dominance of non-pathogenic bacteria in intestinal microflora so that the balance of the chicken gastrointestinal microbiota is stable [21].

\section{Number of Escherichia coli Colonies}

The mean values in Table 3 indicate that the lowest number of Escherichia coli colonies is P3, whereas the highest is PO. The increased concentration of probiotics given the number of colonies Eschericia coli lower. The lowest number of colonies of Escherichia coli is found in P3, according to the study [21] [22].

The decrease in the number of colonies of Escherichia coli can be caused by antimicrobial compounds of probiotics that can suppress growth in the digestive tract. 
Table 3. Mean of Number of Colonies of BAL, Salmonella, Escherichia coli and BAL Ratio with Pathogenic Bacteria

\begin{tabular}{|c|c|c|c|c|}
\hline \multirow{2}{*}{ Mikroflora } & \multicolumn{4}{|c|}{ Treatment } \\
\hline & PO & P1 & $\mathrm{P} 2$ & P3 \\
\hline BAL (CFU) & $6,26 \pm 0,67^{a}$ & $9,58 \pm 0,57^{b}$ & $10,83 \pm 0,29 c$ & $12,22 \pm 0,78^{d}$ \\
\hline Salmonella (CFU) & $3,25 \pm 0,61^{b}$ & $3,24 \pm 0,54^{b}$ & $2,28 \pm 0,35^{b}$ & $1,16 \pm 0,49^{a}$ \\
\hline Eschericia coli (CFU) & $4,87 \pm 0,44^{c}$ & $3,44 \pm 0,44^{b}$ & $2,11 \pm 1,05^{a b}$ & $1,01 \pm 0,48^{a}$ \\
\hline BAL Ratio: Pathogenic Bacteria (\%) & $40,06: 73,40$ & $58,99: 46,34$ & $71,17: 31,24$ & $84,92: 15,69$ \\
\hline
\end{tabular}

This decrease is in line with studies conducted by [21] that probiotics of Lactobacillus $0.75 \%$ in feed can significantly reduce the number of Escherichia coli colonies. Lactobacillus isolated from the cloaca can inhibit the growth of Escherichia coli [23].

\section{BAL Ratio and Microbial Pathogens}

Based on Table 3, it showed that the addition of liquid probiotic (Lactobacillus sp.) to the balance of microflora shows the best ratio of BAL and bacterial pathogens in the addition of probiotics $0.6 \%$ (P3). A good microflora balance is if a beneficial microbe can suppress pathogenic microbes by pushing out the pathogenic microbes [24]. The balance can be achieved if the ratio between microbials favorable to pathogenic microbes is $85: 15$ or $80: 20$ [25]. The results showed that the ratio of P3 was $84.92: 15.69$, it showed that the giving of liquid probiotic Lactobacillus sp. improve the balance of microflora.

\section{Enzyme Activity}

Protease Enzyme Activity

The mean values in Table 4 showed that the activity of the lowest protease enzyme is PO whereas the highest protease enzyme activity was P3.

Numerically an increase with the addition of probiotics was in accordance to previous research [26] [27]. The addition of liquid probiotics can increase the activity of protease enzymes needed in the digestion to break the peptide bond in feed proteins and to free the amino acids needed by the body [28]. These results indicated that the use of probiotics in broilers gave results that vary depending on the factors that influence them including temperature, $\mathrm{pH}$, enzyme concentration, and enzyme inhibitors. Factors that may affect probiotic performance were health status, nutrition, stress, strain and genetic differences in livestock, age, probiotic dose, and frequency of probiotics [1].

The protease enzyme has a function as a catalyst that was to hydrolyze proteins. The accumulation of amino acids that can be absorbed by the small intestine can increase the activity of protease enzymes [8].

\section{Lipase Enzyme Activity}

The mean value of enzyme activity in Table 4 showed that the activity of the lowest lipase enzyme was PO whereas the highest lipase enzyme activity was P3. Numerically an increase with the addition of probiotics, this is in accordance with the study [29]. The addition of liquid probiotics can increase lipase enzyme activity that can break down fat into fatty acids and triglycerides [30]. The process of digesting fat hydrolysis begins in the small intestine, through the activation of bile salts as emulsifiers and subsequently, the fat is broken down by lipase into fatty acids and glycerol [31].

Table 4. Mean of Protease and Lipase Enzyme Activity

\begin{tabular}{lllll}
\hline $\begin{array}{c}\text { Enzyme } \\
\text { Activity } \\
\text { (unit/gram) }\end{array}$ & P0 & P1 & P2 & P3 \\
\hline & $0,0657 \pm$ & $0,0689 \pm$ & $0,0723 \pm$ & $0,0742 \pm$ \\
Protease & 0,0045 & 0,0054 & 0,0018 & 0,0039 \\
& $0,0682 \pm$ & $0,0740 \pm$ & $0,0749 \pm$ & $0,0783 \pm$ \\
Lipase & 0,0054 & 0,0037 & 0,0059 & 0,0101 \\
\hline
\end{tabular}

\section{Number of Intestinal Villi}

The mean values in Table 5 indicated that the lowest intestinal villi count was P0, while the largest number of villi was P3. The increasing concentration of probiotics given the number of intestinal villi was increasing.

An increase in the number of intestinal villi indicated there was an increase in viability of probiotics in the digestion so as to enable an increase in the process of digestion and absorption of food. Increased digestive activity and absorption cause the number of chicken intestine villi can develop well. 
Table 5. Mean of Number and Surface Area of Intestinal Vili

\begin{tabular}{llcll}
\hline \multicolumn{1}{c}{$\begin{array}{l}\text { Intestinal } \\
\text { Histology }\end{array}$} & P0 & P1 & P2 & P3 \\
\hline Number of & & & & \\
villi (unit / & $32,94 \pm$ & $34,11 \pm$ & $36,61 \pm$ & $39,33 \pm$ \\
$\left.10^{3} \mu\right)$ & $2,23^{\mathrm{a}}$ & $2,72^{\mathrm{a}}$ & $3,31^{\mathrm{ab}}$ & $4,35^{\mathrm{b}}$ \\
Villi area & $79,00 \pm$ & $107,73 \pm$ & $167,13 \pm$ & $171,90 \pm$ \\
$\left(\mathrm{m}^{2} \mu\right)$ & $27,59^{\mathrm{a}}$ & $36,45^{\mathrm{ab}}$ & $49,76^{\mathrm{b}}$ & $32,19^{\mathrm{b}}$ \\
\hline
\end{tabular}

Description: Different notations on the same column show very significant differences $(P<0.01)$

This study consistent with [32] [33] that there was a significant effect on the addition of probiotic Bacillus sp. in chicken feed against the number of intestinal villis. This situation caused the absorption of nutrients carried out through the intestinal epithelium would be greater.

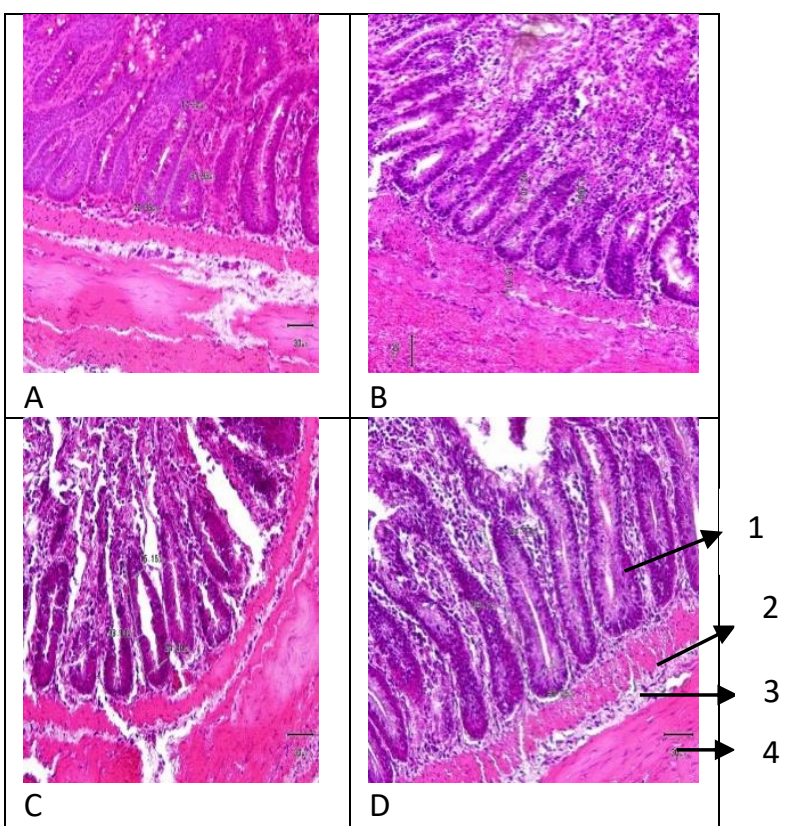

Figure 1. Histology Picture of Intestinal Villi of Broiler after Giving of Liquid Probiotic Lactobacillus sp. (1:30 $\mu \mathrm{m}$ scale)

(A) Intestinal Villi with giving of Lactobacillus sp. P0 (control)

(B) Intestinal Villi with giving of Lactobacillus sp. P1

(C) Intestinal Villi with giving of Lactobacillus sp. P2

(D) Intestinal Villi with giving of Lactobacillus sp. P3

Information :
1. Villi
3. Submucosa
2. Crypta
4. Muscular layer

\section{Surface Area of the Intestinal Villi}

The mean values in Table 5 show the lowest intestinal villi surface area was $\mathrm{PO}$, whereas the highest was P3. The increased concentration of probiotics given then the surface area of the intestinal villi is increasing, this result was in accordance with the study [34]

Giving of probiotics Lactobacillus sp. in broiler feed might increase the height of intestinal villi thus increasing the absorption of intestinal nutrients [35]. The surface area of the intestine to absorb nutrients was larger in chickens that obtain probiotics than those not getting probiotics [36]. Increased height and width of the villi are associated with a wider area of the villi for absorption of nutrients into the bloodstream [36]. The results of the study [3] using the same materials and methods also showed that giving Lactobacillus sp. can decrease the feed conversion and increase body weight.

Figure 1 was a histology overview of the chicken intestine villi from each treatment, the figure shows that the height and width of the villi are different from the controls. Villi is the elucidation of the intestinal mucosa towards the lumen so that the absorption area is wider. Mucus is secreted by the submucosal glands and bowl cells that serve to protect the intestinal villi epithelium against mechanical damage as well as irritation of digestive enzymes [37]. The greater of the surface area of the intestinal villi the more efficient the absorption of nutrients, it was influenced by hormonal, nervous, and digestive gland factors present in the gastrointestinal tract and gland [38].

Increased height and width of the villi can be caused by increased short-chain fatty acids induced by probiotics. Short chain fatty acids are produced from the probiotic bacterial fermentation process that plays a role in the stimulation of intestinal epithelial cell multiplication, and short chain fatty acids are phospholipid components of epithelial membranes [8].

\section{CONCLUSIONS AND SUGGESTION Conclusions}

The addition of liquid probiotic Lactobacillus sp. in the feed can provide a balance of microflora by increasing the number of BAL colonies, decreasing the number of colonies of Salmonella and Eschericia coli, increasing the activity of protease enzymes and lipase, as well as increasing the number and surface area of the intestinal villi.

\section{Suggestion}

The addition of liquid probiotic Lactobacillus $\mathrm{sp}$. in the feed at a concentration of $0.6 \mathrm{v} / \mathrm{w}$ in order to obtain the best performance. 


\section{ACKNOWLEDGEMENT}

1. Prof. Dr. Ir. Woro Busono, MS., Dr. Ir. Osfar Sjofjan, M.Sc., Dr. Ir. Edhy Sujarwo, MS., and Dr. M. Halim Natsir, S.Pt, MP.

2. Mr. Tono as the farm manager in Rejoso, Junrejo

3. Postgraduate Friends of Animal Husbandry Faculty of Brawijaya University 2013

4. All relevant parties that assist the completion of this research

\section{REFERENCES}

[1]. Soeharsono. 2010. Probiotik. Basis Ilmiah, Aplikasi dan Aspek Praktis. Penerbit Widya Padjadjaran. Bandung.

[2]. Reid G. 2006. Probiotics to prevent the need for, and augment the use of, antibiotics. J Infect Dis Med Microbiol. 17(5): 291-295.

[3]. Astuti, F.K., W. Busono dan O. Sjofjan, 2015. Pengaruh penambahan probiotik cair (Lactobacillus sp.) dalam pakan terhadap Penampilan Produksi Ayam Pedaging. J-PAL, Vol 6, No.2, 2015.

[4]. Suryahadi dan AS. Tjakradidjaja. 2012. Pengujian mutu dan efikasi probiotik biofeed dan turrimavita. Laporan penelitian. Bogor (ID): Institut Pertanian Bogor.

[5]. Sjofjan, O., T. Ardyati, dan M.H. Natsir. 2013. Inovasi produksi probiotik tepung "probiss" sebagai upaya peningkatan produktivitas kesehatan dan peternakan unggas yang ramah lingkungan. Riset Andalan Perguruan Tinggi dan Industri. Lembaga Penelitian dan Pengabdian Masyarakat Universitas Brawijaya. Malang.

[6]. Husmaini. 2009. Isolation and identification of latic acid bacteria from waste processing virgin coconut oil with the biolog microstation. International Seminar and Workshop Biodiversity, Biotechnology and Crop Production. Padang, 17-18.

[7]. Harimurti, S. dan E.S. Rahayu. 2009. Morfologi usus ayam broiler yang disuplementasi dengan probiotik strain tunggal dan campuran. Agritech, Vol. 29, No. 3.

[8]. Gunal, M., G. Yayli, O. Kaya, N. Karahan dan O. Sulak. 2006. The effect of antibiotics growth promotor, probiotic or organic acid suplementation on perfomance, intestinal microflora and tissue af broilers. International Journal of Poultry Science 5: 149-155.

[9]. Sakamoto, K., H. Hirose, A. Onizuka, M. Hayashi, N. Futamura, Y. Kawamura, and T.
Ezaki. 2000. Quantitative study of changes in intestinal morphology and mucus gel on total parenteral nutrition in rats. J. Surg. Res. 94:99-106.

[10]. Bergmeyer. 1984. H.U. Methods of Enzymatic Analysis. Verlag Chemie. Deerfield Beach Florida Basel.

[11]. Lestariningsih, Sjofjan O, dan Surisdiarto. 2012. Pengaruh penggunaan fitobiotik sebagai aditif pakan terhadap penampilan produksi ayam pedaging. Fakultas Peternakan Universitas Brawijaya. Malang.

[12]. Steel, R.G.D., and J.H. Torrie. 1997. Principles and Procedures of Statistics, 3rd, ed. McGraw Hill.

[13]. A.C. Murry, Jr., A. Hinton, Jr. and R.J. Buhr. 2006. Effect of Botanical Probiotic Containing Lactobacilli on Growth Performance and Populations of Bacteria in the Ceca, Cloaca, and Carcass Rinse of Broiler Chickens. International Journal of Poultry Science 5 (4): 344-350

[14]. Mountzouris, K. C., P. Tsirtsikos, E. Kalamara, S. Nitsch, G. Schatzmayr, and K. Fegeros. 2007. Evaluation of the efficacy of a probiotic containing Lactobacillus, Bifidobacterium, Enterococcus, and Pediococcus strains in promoting broiler performance and modulating cecal microflora composition and metabolic activities. Poult. Sci. 86:309-317.

[15]. Chimanage P, V. Hirunvong, P. Sirirote, W. Malaphan, B. Yongsmith, S. Isariyodom, C. Tirawattanawanich, W. Chitanont and P. Talsook. 2015. Effect of feed supplementation of lactic acid bacteria on microbial changes in broiler intestine. Kasetsart J. (Nat. Sci.) $42: 269-276$.

[16]. Joerger, R.D., 2003. Alternatives to antibiotics : bacteriocins, antimicrobial peptides and bacteriophages. Poult. Sci., 82 : 640-647.

[17]. Collado, M. C., E. Isolauri, S. Salmien, and Y. Sanz. 2009. The impact of probiotic on gut health. Curr Drug Metab. 10(1):68-78.

[18]. Higgins, S.E., J.P. Higgins, A.D. Wolfenden, S.N. Henderson, A. Torres rodriguez, G. Tellez and B. Hargis. 2008. Evaluation of a Lactobacillus-Based Probiotic Culture for the Reduction of Salmonella entritidis in Neonatal Broiler Chicks. J. Poultry Science 87:27-31. Doi:10.3382/ps.2007-00210

[19]. Revolledo, L., A.J.P. Ferreira, and G.C. Mead. 2006. Prospects in Salmonella Control : Competitive Exclusion, Probiotics, and 
enhancement of Avian Intestinal Immunity. J. Appl. Poult. Res. 15:341-351.

[20]. Tellez, G., C. Pixley, R.E. Wolfenden, S.L. Layton, B.M. Hargis. 2012. Probiotics/Direct Fed Microbials

[21]. Kabir, S.M.L. 2009. The role of probiotics in the poultry industry. International Journal esof Molecular Sciences. ISSN 1422-0067.

[22]. Forte, C., G. Acuti, E. Manuali, P. Casagrande, S. Pavone, M. Trabalza, L. Moscati, A. Onofri, C. Lorenzetti, and M.P. Franciosini. 2016. Immunology, health and Disease. Effects of two differnet probiotic on microflora, morphology and morphometry of gut in organic laying hens. Poultry Science Association Inc.

[23]. Miyamoto, T., T. Horie, T. Fuiiwara, T. Fukata and K. Sasai, 2000. Lactobacillus flora in the cloaca and vagina of hens and its inhibitory activity against Salmonella enteritidis in vitro. Poult. Sci., 79: 7-11.

[24]. Fuller, R. 2002. Probiotics in man and animals. J. Appl. Bacteriol. 66: 365-378.

[25]. Husmaini. 2009. Isolation and Identification of latic acid bacteria from waste processing virgin coconut oil with the biolog microstation. International Seminar and Workshop Biodiversity, Biotechnology and Crop Production. Padang, 17-18.

[26].Yong H.P., F. Hamidon, C. Rajangan, K.P. Soh, C. Y. Gan, T. S. Lim, W. N. W. Abdullah, and M. T. Liong. 2016. Application of Probiotics for the Production of Safe and High Quality Poultry Meat. Korean J. Food Sci. An. Vol 36 No 05, pp 567-576.

[27]. Wang Y, and Q. Gu. 2010. Effect of probiotic on growth performance and digestive enzyme activity of arbor acres broilers. Res Vet Sci. doi : 10.1016/j.rvsc.2010.03.009.

[28]. Fazarwati, M.N., E. Widodo, dan I. H. Djunaidi. 2013. Effect of foxtail millet (Setaria italica sp) use as feed to substitute yellow corn on broiler's intestinal enzymatic activity animal nutrition, Faculty of Animal Husbandry, Brawijaya University, Malang.

[29]. Zhang, L.. Zhang, X. Zhan et al. 2016. Effects of dietary supplementation of probiotic, Clostridium butyricum, on growth performance, immune response, intestinal barrier function, and digestive enzyme activity in broiler chickens challenged with Eschericia coli K88. Journal of Animal Science and Biotechnology. DOI 10.1186/s40104-016-0061-4.
[30]. Liong, M.T and N.P Shah. 2005. Bile salt deconjugation ability, bile salt hydrolase activity and cholesterol co-precipitation ability of Lactobacillus strains. International Dairy Journal. Vol. 15: 391-398.

[31]. Yasin, I. 2010. Pencernaan serat kasar pada ternak unggas. Jurnal IImiah Inkoma, Volume 21, Nomor 3.

[32]. Sjofjan, O. 2003. Kajian probiotik (Aspergillus niger dan Bacillus sp.) sebagai imbuhan ransum dan implikasinya terhadap mikroflora usus serta penampilan produksi ayam petelur. Disertasi. Universitas Padjadjaran, Bandung.

[33].Kompiang, I. P. 2009. Pemanfaatan mikroorganisme sebagai probiotik untuk meningkatkan produksi ternak di Indonesia. Pengembangan Inovasi Pertanian 2 (3) 177191.

[34]. Forte, C., E. Manuali, Y. Abbate, et al. 2018. Dietery Lactobacillus acidophilus positively influences growth performance, gut morphology, and gut microbiology in rurally reared chickens. Poultry Science Vol 97. Pages 930-936.

[35]. Awad W.A., K. Ghareeb, and J. Böhm. 2010. Effect of addition of a probiotic microorganism to broiler diet on intestinal mucosal architecture and electrophysiological parameters. Abstract J Anim Physiol Anim Nutr (Berl). 2010 Aug 1;94(4):486-94. doi: 10.1111/j.14390396.2009.00933.x.

[36]. Mile, R.D., G.D. Butcher, P.R. Henry, dan R.C. Littell. 2006. Effect of antibiotic growth promoters on broiler performance, intestinal growth parameters, and quantitative morphology. Journal of Poultry Science 85: 476-485.

[37]. Dellmann, H.D. and M.E.Brown 1992. Buku Teks Histologi Veteriner II. Universitas Indonesia Press. Jakarta. Hal 375-388.

[38]. Guyton, A.C. 1997. Fisiologi Kedokteran. Edisi 9. Universitas Indonesia Press. Jakarta 